\title{
UPWARD TRANSITION OF INDIAN ENTREPRENEURS: FROM SIMPLE WORKING TO ETHNIC ENTREPRENEURSHIP. A CASE STUDY IN AN ITALIAN REGION
}

Rahmat Alì Mohammed ${ }^{1}$, Marcello De Rosa², Maria Angela Perito ${ }^{3}$

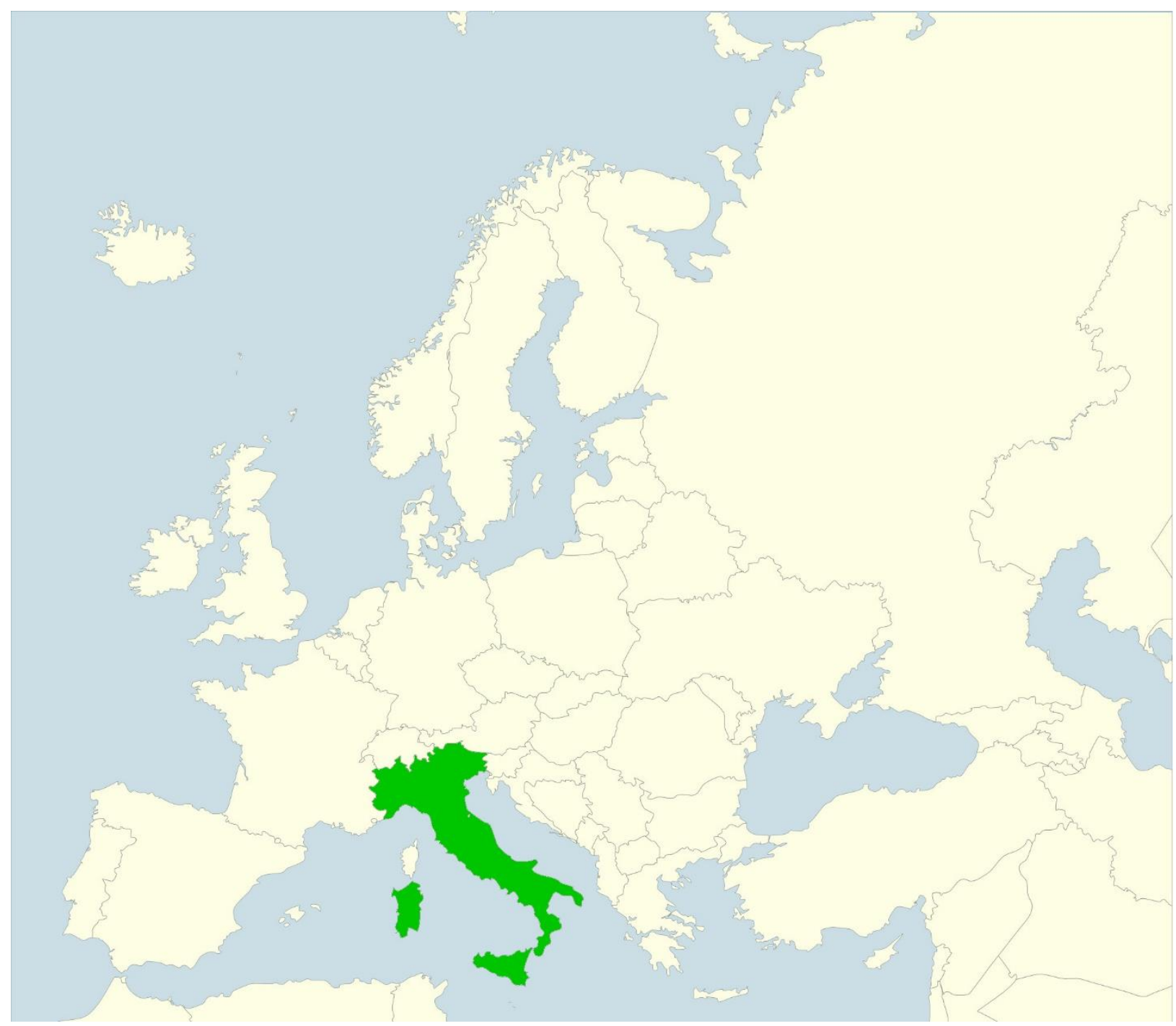

\footnotetext{
${ }^{1}$ Rahmat Ali Mohammed, University of Cassino and Southern Lazio, Italy, e-mail: rahmath46@gmail.com, ORCID: 0000-0002-1610-7860.

2 Marcello De Rosa, PhD., corresponding author, University of Cassino and Southern Lazio, Italy, e-mail: mderosa@inicas.it, ORCID: 0000-0002-5053-6861.

${ }^{3}$ Maria Angela Perito, PhD., University of Teramo, Italy and INRA, UR1303, ALISS, Ivry-sur-Seine, France, e-mail: maperito@unite.it, ORCID: 000-0002-3115-1288.
} 
Abstract: This paper explores the role of entrepreneurial orientation in addressing upward mechanisms of Indian immigrant workers in rural areas. To achieve this purpose, an empirical analysis was carried out to investigate how entrepreneurial orientation may affect mechanisms of professional transition. Precisely, we managed direct interviews among Indian workers (through the support of cultural mediators), local actors (like public and private advisors) and Italian entrepreneurs. Our funding suggests the presence of three Indian workers in Italy (simple workers, intrapreneurs, entrepreneurs), characterised by different entrepreneurial profile acting as engine or barrier to what we have labelled as "upward transition". Immigrant entrepreneurs play a relevant role in Italy and in our point of view, it is of paramount importance to allow them to access to rural development policies, knowledge, training and education upgrading.

Keywords: ethnic rural entrepreneurship; entrepreneurial orientation; upward transition; Indian immigrants, Italian agriculture

Abstract: L'articolo analizza il ruolo dell'orientamento imprenditoriale nel favorire meccanismi di progressione dei lavoratori indiani impiegati nelle aree rurali italiane. Per raggiungere questo obiettivo, l'attività di ricerca è stata incentrata su un'analisi empirica volta ad indagare l'orientamento imprenditoriale e come esso possa influenzare i meccanismi di transizione professionale. In particolare, abbiamo condotto delle interviste dirette ai lavoratori indiani (attraverso il supporto di mediatori culturali), attori locali (come consulenti pubblici e privati) e imprenditori italiani. I nostri risultati suggeriscono la presenza di tre categorie di lavoratori indiani in Italia (semplici lavoratori, intraimprenditori, imprenditori), caratterizzati da diversi profili d'imprenditorialità come motore/barriera di un fenomeno che abbiamo nominato come "transizione verso l'alto". Gli imprenditori immigrati svolgono un ruolo rilevante in Italia e dal nostro punto di vista è di fondamentale importanza consentire loro di accedere alle politiche di sviluppo rurale, ai processi migliorativi delle conoscenze, alla formazione e all'istruzione.

Keywords: imprenditorialità rurale etnica, orientamento imprenditoriale, transizione ascendente, immigrati indiani, agricoltura italiana

\section{Highlights}

- Ethnic entrepreneurship is a relevant phenomenon typifying rural areas

- Entrepreneurial orientation may affect the transition from simple workers to agricultural entrepreneurs

- Networking and social capital may be key resources in this transition

- Rural development policies should encourage upward transition of immigrant workers

\section{Introduction}

The theme of workforce development in farming activity is becoming increasingly important within the field of farming systems research. This paper deals with ethnic rural entrepreneurship, a phenomenon which is interesting many rural areas of Europe in the last decades and holding importance in affecting transformation of the European countryside. As a matter of fact, a study conducted for the European commission by the Joint research centre (EU-JRC, 2019) underline the relevance of migrant workers in EU rural areas, where foreign workers take on a fundamental role in the farming sector characterised by growing demand of temporary work. More precisely, from 2011 to 2017, share of migrant workers in the EU agricultural sector raised from $4.3 \%$ to $6.5 \%$ (Eurostat, various years). As evidenced in aforementioned study, jointly with Spain and 
Denmark, Italy is one of the countries with a relatively higher incidence of migrants among total employed in farming sector, with a shift from 6\% in 2011 to 9\% in 2017 (EU-JRC, 2019). Therefore, Italy represents an interesting case-study. The aim of the paper is to analyse the role of foreign workers' entrepreneurial orientation in boosting transition from simple workers to rural entrepreneurs. The underlying hypothesis is that entrepreneurial orientation may act as the engine of "upward transition" from simple workers to entrepreneurship.

The work focuses on Indian workers in a rural area of Italy, where the Indian population has been steadily increasing over time, being currently 7th largest foreign community in Italy (Macri, 2019). This phenomenon will be explored through the lens of entrepreneurial orientation, by taking into account three potential positions occupied by immigrant workers: simple workers, intrapreneurs, entrepreneurs.

The paper is articulated as follows: in the next session we will provide a synthetic theoretical background, by emphasising a gap in literature, related to the lack of studies on ethnic entrepreneurship in the Italian agriculture. The following empirical analysis will be carried out with a case-study in a rural region of Italy. Three ideal-type of farmers-entrepreneurs are selected by clarifying their entrepreneurial orientation and by enlightening its role in performing their entrepreneurial attitude. Some final conclusions and policy implications will finalise the paper.

\section{Theoretical background}

Ethnic entrepreneurship, which concerns business activities carried out by immigrant workers with specific sociocultural and ethnic background (Sahin et al., 2007), has recently attracted interest of many scholars. As underlined in recent literature, analysis of immigrant entrepreneurship involves multidisciplinary approaches, ranging from business and sociology to international entrepreneurship and migration studies (Dabić et al., 2020). Moreover, rural areas have become attractive for migrant workers, in account of the high demand for cheap labour force, to be employed in agricultural activities (Rye and Slettebak, 2020; Rye and Andrzejewska, 2010).

Immigration can be essential for rural economic development because it brings new people into the community with fresh ideas and entrepreneurial skills (Stockdale, 2006; Kalantaridis and Bika, 2006; Kalantaridis, 2010), then bringing about the possibility for them to "shape" the rural countryside.

Immigrant entrepreneurs represent an interesting phenomenon, which offers a diversified set of motivation for upgrading entrepreneurship, through cross-fertilization, sharing of experience, etc. (Saxenian, 2002). Recent researches have demonstrated the positive impact of return migration for revitalizing local communities (Kordel, Lutsch, 2018). Entrepreneurial orientation seems stronger in immigrant workers with respect to native ones, as emphasised in recent studies (for instance, Bluestein 2015), underlying also higher levels of creativity (Freire-Gibb and Nielsen, 2014).

In order to mark differences from "mainstream entrepreneurship", minority and ethnic entrepreneurship have been analysed in literature from two different points of view (Wang and Altinay, 2012):

- the "cultural approach" is drawn on strong ties and evidences community links and embeddedness as engine of entrepreneurship. According to this strand, ethnocultural milieu is shaped by both entrepreneurial and non-entrepreneurial dimensions (Dana, 1997). Furthermore, community and family ties represent a sound basis for counting on labour power and financial resources (Hamilton et al., 2008);

- the "structuralist approach", according to which "ethnic minorities start up their own businesses not because the unique advantage associated with their ethos, culture or embeddedness in the ethnic community, but because self-employment is one of the most effective strategies for ethnic minority individuals to pursue upward socio-economic mobility" (Blundel et al., 2018, 21). As a consequence, entrepreneurship is the only strategy to escape high barriers in the labour markets (Zhou, 2004), despite some scholars cast some doubts about the effectiveness of this strategy in terms of economic integration 
(Brzozowski and Lasek, 2019). This approach holds points of contact with the disadvantage theories suggesting that immigrants set up their own businesses as this is practically the only way that they can earn a living in a new country; it is, therefore, a form of necessity - (forced) entrepreneurship" (Dabić et al., 2020, p.28).

This paper is drawn on both perspectives. As a matter of fact, by looking into the "why" question on entrepreneurship, cultural approach provides insights on pull motivation (grounded on a proactive strategy) for entrepreneurship, while structuralist approach is at the basis of the push motivation for ethnic entrepreneurship (reactive strategy) (Methorst et al., 2017; Jones et al., 1985). Against this background, the paper tries to evaluate the relevance of entrepreneurial orientation (EO) either in shaping farmer's identity and in boosting upward transition toward ethnic entrepreneurship. How to explore EO is a not an easy task and calls for multidisciplinary approaches which may be synthesised in three main perspectives (Omisakin et al., 2016; Mitchell et al., 2002): economic (creation of new venture and organisation's entrepreneurial and performance level), socio-psychological (entrepreneur's individual values and traits) and strategic management (strategic organisational objectives).

The analysis is carried out in a rural area of Italy. The role of immigrants in Italian agriculture has been analysed in recent years (Pisacane, 2017), with the aim to explore either their impact on agricultural productivity (Baldoni et al., 2017), or their role as workforce in the diversified set of agricultural activities (Coderoni et al., 2018), or exploring their role in multifunctional agriculture of Italy (De Rosa et al., 2019). Less attention has been devoted to phenomena of ethnic entrepreneurship, in particular to entrepreneurial attitude as engine to upward transition from simple workforce to entrepreneurial positions. This paper tries to fill a gap in literature, with a preliminary exploratory analysis of different configuration of Indian workers in the fruit and vegetable sector of Italy.

\section{Immigrants workers in Italy. An overview}

Foreign citizens in Italy increased significantly in the last 30 years (Coderoni et al., 2018). According to the Italian Institute of Statistics (ISTAT, 2018), from 2008 to 2016, the share of foreigners on total agricultural labour forces in Italy has grown from 6 to $16 \%$ (from 51,039 to 146,924 units).

More than a third of non-EU citizens in 2016 came from Albania, Morocco and China (Figure 1). India was the seventh country of origin of foreign workers employed in agriculture with nearly 91,000 units in 2016 (Figure 1) and 93,688 in 2018 (Table 1). In particular, the migratory flow from Asia has greatly increased: compared to 2007, workers from India and Bangladesh have more than doubled (Macrì, 2019).

According to the Italian institute of statistics, half of Indian workers are located in the regions Lombardy (29.9\%) and Lazio (19.3\%) (Table 1).

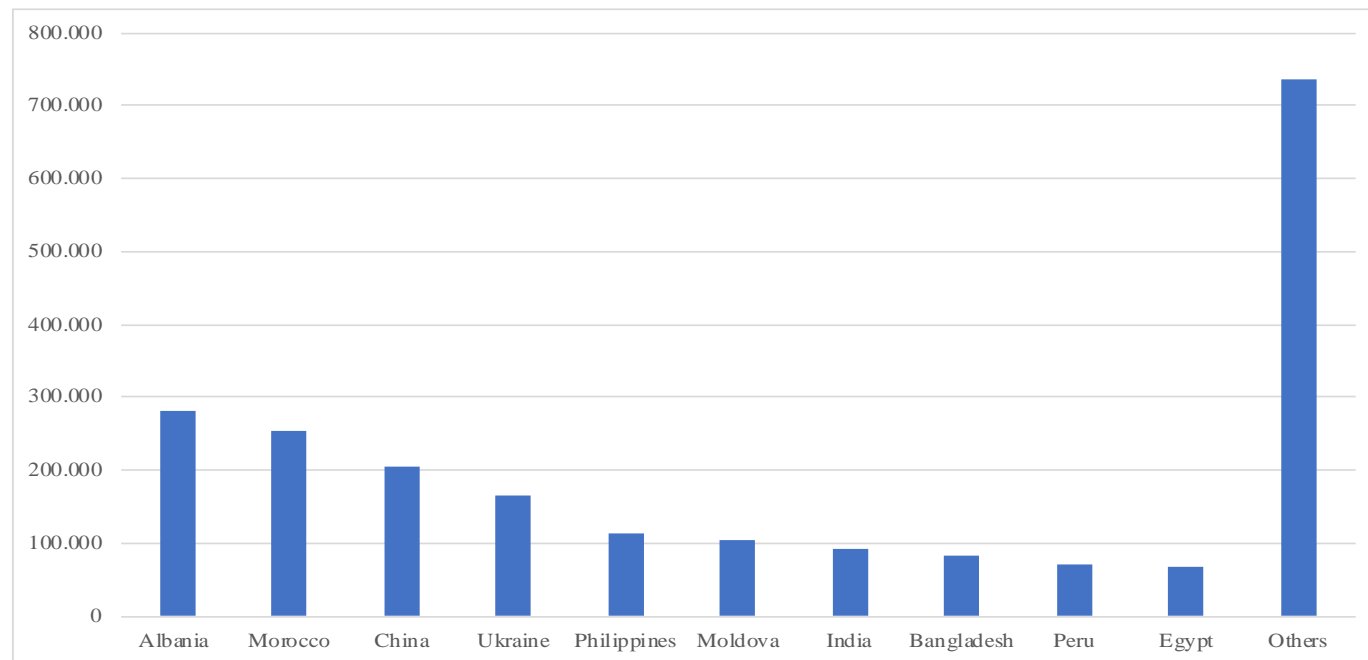

Fig 1. Countries of origin of foreign workers (Year 2016). Source: Macrì (2019). 
Our empirical analysis will focus on the region Lazio, in central Italy, more precisely on the province of Latina (figure 2).

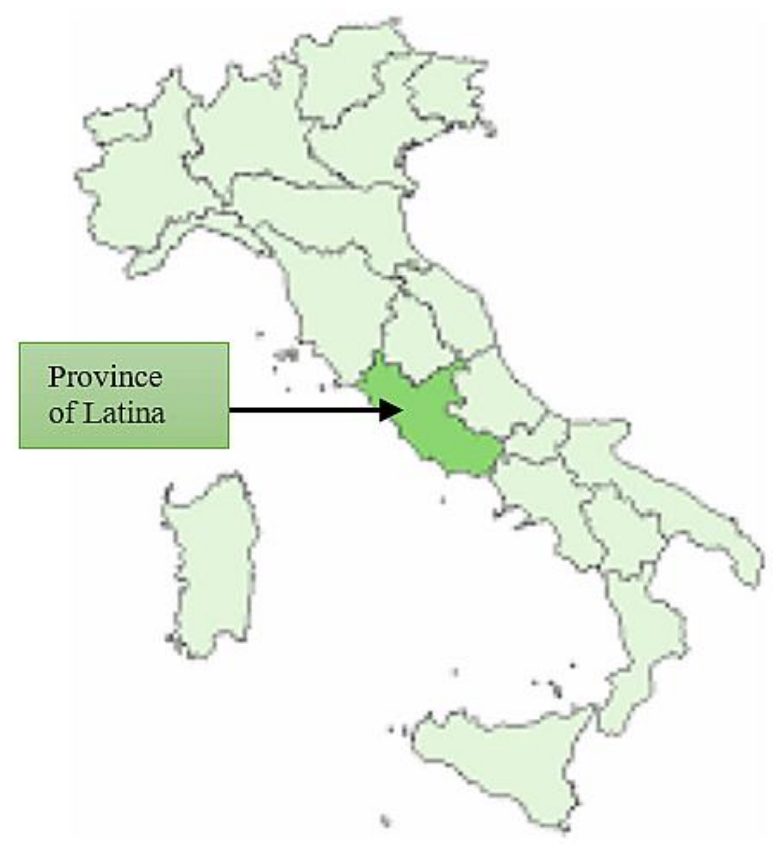

Fig 2. Area under investigation. Source: self-elaboration

As evident from Table 1, this region has the second place as incidence of Indian residents, with provinces of Rome and Latina as the most relevant (Table 2), respectively with $57.8 \%$ and $38.3 \%$ due to its specialization in agricultural sectors. In particular, the province of Latina is really attractive for Indian workers in the fruit and vegetable sector and in livestock (Table 2). Actually, Indians are skilled workers in these sectors and hold competencies from the country of origin.

Tab 1. Number of Indian residents by regions and percentage change between 2019 and 2013. Source: ISTAT - Data on international migration and the foreign presence in Italy

\begin{tabular}{|l|r|r|c|c|c|}
\hline \multicolumn{1}{|c|}{ Regions } & 2013 & 2019 & $\begin{array}{c}\text { percentage } \\
\text { change } \\
2019 / 2013(\%)\end{array}$ & $\begin{array}{c}\% \\
(2019)\end{array}$ & $\begin{array}{c}\text { \% on all } \\
\text { the foreign population in } \\
\text { the region (2019) }\end{array}$ \\
\hline Abruzzo & 642 & 926 & 44.2 & 0.6 & 1.1 \\
\hline Basilicata & 777 & 1.019 & 31.1 & 0.6 & 4.4 \\
\hline Calabria & 3.548 & 4.622 & 30.3 & 2.9 & 4.2 \\
\hline Campania & 5.013 & 8.272 & 65.0 & 5.1 & 3.1 \\
\hline Emilia-Romagna & 17.297 & 18.199 & 5.2 & 11.3 & 2.3 \\
\hline Friuli-Venezia Giulia & 2.410 & 2.692 & 11.7 & 1.7 & 4.5 \\
\hline Lazio & 22.239 & 31.038 & 39.6 & 19.3 & 1.4 \\
\hline Liguria & 1.715 & 2.114 & 23.3 & 1.3 & 4.0 \\
\hline Lombardy & 49.842 & 48.097 & -3.5 & 29.9 & 3.1 \\
\hline Marche & 4.167 & 4.184 & 0.4 & 2.6 & 4.0 \\
\hline Molise & 475 & 531 & 11.8 & 0.3 & 1.3 \\
\hline Piedmont & 4.127 & 5.530 & 34.0 & 3.4 & 2.9 \\
\hline Puglia & 2.764 & 4.110 & 48.7 & 2.6 & 1.1 \\
\hline Sardinia & 512 & 616 & 20.3 & 0.4 & 1.6 \\
\hline Sicily & 1.733 & 1.968 & 13.6 & 1.2 & 2.5 \\
\hline Tuscany & 5.996 & 6.815 & 13.7 & 4.2 & 1.6 \\
\hline Trentino Alto Adige & 1.831 & 2.424 & 32.4 & 1.5 & 0.8 \\
\hline Umbria & 1.546 & 1.616 & 4.5 & 1.0 & 3.2 \\
\hline Aosta Valley & 62 & 68 & 9.7 & 0.0 & 3.0 \\
\hline Veneto & 15.757 & 16.260 & 3.2 & 10.1 & \\
\hline Italy & 142.453 & 161.101 & 13.1 & 100.0 & \\
\hline
\end{tabular}


Tab 2. Number of Indian residents by Lazio provinces and percentage change between 2019 and 2013. Source: ISTAT - Data on international migration and the foreign presence in Italy

\begin{tabular}{|l|r|r|r|r|r|}
\hline Provinces & \multicolumn{1}{|c|}{2013} & 2019 & $\begin{array}{c}\text { Percentage change } \\
2019 / 2013(\%)\end{array}$ & $\begin{array}{c}\text { Incidence rate } \\
\text { ratio }\end{array}$ & $\begin{array}{c}\text { Incidence rate ratio on } \\
\text { the foreign population (\%) }\end{array}$ \\
\hline Frosinone & 307 & 432 & 40.7 & 1.4 & 1.6 \\
\hline Latina & 7617 & 11.880 & 56.0 & 38.3 & 21.5 \\
\hline Rieti & 184 & 229 & 24.5 & 0.7 & 1.7 \\
\hline Rome & 13.686 & 17.948 & 31.1 & 57.8 & 3.2 \\
\hline Viterbo & 445 & 549 & 23.4 & 1.8 & 1.7 \\
\hline Total & 22239 & 31.038 & 39.6 & 100.0 & 4.5 \\
\hline
\end{tabular}

Foreign workers absorb a large and increasing share of the Italian agricultural labour force. According to De Leo and Vanino (2019), Romanians, Moroccans, Indians and Albanians are the most important. These workers are attracted by numerous factors, such as access to food and accommodation. Moreover, demand for skills and capacities often meets those of incoming population. As far as farming style is concerned, immigrant workers are mainly employed within big conventional farms (De Rosa et al., 2019). Furthermore, as in other parts of Europe, small farms located in peripheral regions tend to be strongly embedded in their local communities (European Union, 2018; Besser and Miller, 2001, 2013; Lähdesmäki and Suutari, 2012; Steiner and Atterton, 2015), which may accelerate integration processes. Many low-skilled migrants are involved in intensive farming and in high-yielding areas, where they provide services as seasonal agricultural workers (Nori, 2017).

This study focuses on Indians in conventional farming, with special reference to farms located in an agricultural area specialized in fruit and vegetable production.

\section{Materials and method}

The empirical analysis is carried out in fruit and vegetables sector of the province of Latina, in the region Lazio of Italy. The local district absorbs a relevant part of the value of production at national level. Here, a significant share of foreign workers has gained importance in last years, with a relevance of Indian workers, employed also in the livestock sector.

With the purpose of investigating how entrepreneurial orientation may affect mechanisms of professional transition to entrepreneurship among immigrant Indian workers, a qualitative methodology based on case studies is adopted (Yin, 2008). More precisely, narrative analysis is carried out, in order to acquire information on the evolutionary process that have typified these workers (Dawson and Hjorth, 2011).

By following Smith and McElwee's (2014), in order "to put quality into qualitative research", participant observation, structured and semi-structured interviews have been realised (Aoyama et al., 2010). More precisely:

- we have administered 10 direct semi-structured interviews conducted on a purposive sample of Indian famers, belonging to the Sikh community and occupying different positions in fruit and vegetables sector:

- five Indians are simple workers, mainly involved in the harvesting activities;

○ three are employed as intra-preneurs in the processing phase, taking care of monitoring the respect of product quality attributes;

○ two are agricultural entrepreneurs managing a farm.

The Indians are located in the province of Latina, within a highly specialised area in the vegetable sector. We have privileged ethnographic approaches, in account of their utility in catching cultural processes, embeddedness of human beings in such processes (Owusu-Daaku and Onzere, 2019). Furthermore, in order to acquire more information about the transition process, in addition to the Indian entrepreneurs, we also managed direct interviews with local actors, like public and 
private advisors, Italian entrepreneurs, with the aim to qualify for the role and the dynamics of entrepreneurial processes among Indian farmers.

Interviews were administered in the period March-October 2019. The choice of Indians to be interviewed was not easy, due to the difficulty of gaining information from tight-lipped workers. It should not be overlooked that, in general, institutional distance and liability of foreignness typify the presence of immigrant workers in foreign countries (Gurău et al., 2020). Moreover, in agricultural sector, high rates of informality may be found. But, differently from other cases, where informality may represent an opportunity (Chreneková et al., 2016), here informality is linked to illegality, with foreign workers obliged to operate in difficult conditions (Barbieri et al., 2015; Low and Davenport, 2018; Anderson et al., 2006). Recent episodes in the province under study have shed a light on the phenomenon of illegal hiring of workers, well known as "caporalato".

As evidenced by De Rosa et al. (2018), many invisible workers are employed in agricultural activity, which reinforces the renegade side of economy (Webb et al., 2009) and creates conditions of fear among foreign workers. This invisibility makes agriculture a relevant 'entry point' for irregular migrants and provides the setting for illegal practices and exploitation.

Against this background, it is not easy to gain access to sound information and this provides an explanation of the limited sample. In order to do interviews, an interpreter was contacted, who helped us to interview the Indian workers outside the workhours. With the purpose of getting highly affordable information, we tried to conquer their confidence, step by step.

Three main categories of workers have been interviewed, evidenced in Figure 3: simple workers, intrapreneurs and entrepreneur. Senior and highly skilled position is located at the top of the triangle, with respect to basic ones located at the bottom of the figure.

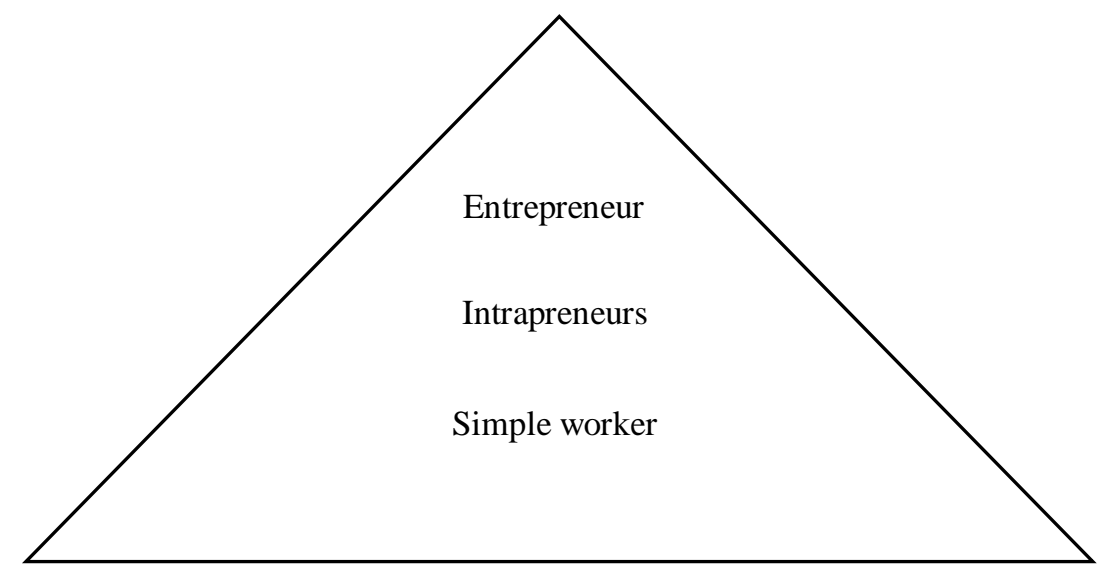

Fig 3. Categories of workers under investigation. Source: self-elaboration

The submitted questionnaire focuses on McElwee and Smith's (2012) segmentation framework by focusing on personal characteristics of the farmers, business characteristics and business activities and processes. Moreover, in order to draw out the farm's entrepreneurial identity, we applied Vesala et al.'s (2007) entrepreneurial identity model, which distinguishes two main dimensions: economic values and individualistic values. Questions submitted for the selfcategorisation of the interviewed are drawn on Vesala et al.'s (2007) work for both economic and individual values.

Economic values are following:

- Innovativeness: it is the inclination to search, develop and find new products/services, new markets, and processes.

- Risk-taking: it is the propensity to take calculated economic risks, such as borrowing or committing significant resources, and bear the state of uncertainty due to the possibility of failure.

- Growth orientation: it is the aim of maximizing profit through the expansion of economic activities and growing the firm. This dimension refers to the assumption that entrepreneurs 
are expected to aim for growth, and that they are not satisfied with simply earning their own living.

Individualistic values are the following:

- Self-efficacy: it refers to a person's capability of performing those actions that are needed to achieve the desired outcomes and goals.

- Optimism: the belief in one's success.

- Personal control: the entrepreneur's belief in the capability of personally affecting or controlling the outcomes of his/her pursuit.

Tab. 3 Respondents were asked to classify the degree of each value according to the following Likert scale (value from 1 to 5):

\begin{tabular}{|c|c|c|c|c|}
\hline $\begin{array}{c}\text { Strongly } \\
\text { disagree }\end{array}$ & Disagree & Neutral & Agree & $\begin{array}{c}\text { Strongly } \\
\text { agree }\end{array}$ \\
\hline 1 & 2 & 3 & 4 & 5 \\
\hline
\end{tabular}

\section{Results}

Most of the respondents arrived in Italy after 2005 and were from Punjab, some from the outskirts of Ludhiana, other from the capital Chandigarh. The provenance of immigrants from these areas was boosted by the presence of local Indian facilitators acting as mediators between demand and supply of work in the local farms. All Indian immigrants state that they left their nation due to financial reasons (troublesome economic conditions, unemployment). The purpose was to enhance their living conditions, begin another family, and get the opportunity to procure enough to run another business in India or in Italy.

In Italy, they were given a wide range of occupations, all low-skilled and labour escalated. Conditions are troublesome, in the case of working outside in the sun in the mid-year or the virus in winter or working inside nurseries where the air is hot and stuffy.

The occupations are altogether done by hand or with the assistance of a few tools, and all include the persistent and enormous utilization of strength, hands, arms. This hardworking activity boost some Indian to try upward transition towards self-employment.

\subsection{Entrepreneurial identity of farmers}

After conducting a survey on migrated workers from India to the region Lazio, we have analyzed three categories of the working population like simple workers, intrapreneurs, and entrepreneurs.

\subsubsection{Simple Workers}

Before coming to Italy, simple workers had been already working in the agricultural fields and are professional in this type of work. Thanks to this experience, they were invited by the entrepreneurs from Italy to work in their agricultural fields as seasonal agricultural workers. However, later on, thanks to their skills and professionalism, they were hired as regular workers. Despite their experience in farming, these Indian workers had to face some difficulties in the initial days because there is a lot of difference in terms of working environment in Italy compared to India. As a matter of fact, agriculture in Italy is technologically more advanced than in India, so they had to adapt to this technology in their day to day working. The degree of satisfaction of entrepreneurs who employed these workers is really high: "Indeed, these people are doing a great job and contributing immensely for the rapid growth of agriculture business in Italy".

Entrepreneurial orientation is not highly developed in these workers: first of all, they lack of growth orientation and innovativeness. They are hoping for financial growth but do not show enthusiasm and ideas on how to carry out this growth aspiration. The resignation about their condition prevails. 
The second economic value is risk-taking: to become an entrepreneur, one has to take the calculated risk financially or any other way. But unfortunately, simple workers cannot afford to take even a little bit of risk because of their poor family financial situation back in India.

The psychological side reveals a relatively low individual disposal towards more entrepreneurial positions. As a matter of fact, these workers are not really optimistic about their condition and they do not really seem to believe in themselves. Being optimistic is very essential for everyone to do better in their respective fields, as well as self-efficacy. As confirmed by interviews with other expert witnesses, these workers have low personal control, that is they do not trust themselves about the capability of personally controlling the success of a firm.

These simple workers possess professional skills since they already worked in India and have worked in the same field of work for years; but this people lack management skills which include financial management, human resource management. Since they are not very well educated and do not have experience in it.

Finally, these workers mostly face legal barriers since they have temporary stay permits. It is difficult for a simple worker to grow with high speed when he has a temporary stay permit. Local language is also an important barrier which they come across. Cultural integration, through the acquisition of language skills, is an element of primary importance for the possibility of growth of simple workers.

\subsubsection{Intrapreneurs}

Intrapreneurs behave like "middle-managers" within large organizations, thanks to their competencies. Even these Indians migrated as seasonal workers from the northern part of India and from agricultural families. Therefore, every intrapreneur came through the phase of simple workers to move towards the position of a middle, manager, that is an intrapreneur who is more than the simple worker and less than entrepreneur. This occurred also thanks to learning processes which, according to our expert witnesses, were also sustained by private and public institutions organizing training courses for upgrading their professional and entrepreneurial competencies. Moreover, upward transition from simple working to intrapreneurship is boosted by entrepreneurial orientation. Intrapreneurs are more innovative in the way they plan their work vision and they have a growth orientation of their activities. Moreover, the intrapreneurs have the ability to take a risk when it is required, by taking on responsibility in the business. In the farms, they got responsibility of quality management, which is of paramount importance in the agrifood sector, in account of the strict rules for accessing modern retailing system in Italy. These workers have a very high level of professional skills as they have been working in agriculture since many years like simple workers. The intrapreneurs are responsible for the whole management of the business and they manage this task very efficiently.

Additionally, they show a relatively low level of optimism regarding the future growth of the farm and their personal growth. These intrapreneurs have the ability to become entrepreneurs and have high levels of self-efficacy, declaring their personal characteristics as suitable for entrepreneurship. Nonetheless, they think they cannot due to legal barriers (lack of permanent citizens of the country). This limits their attitude to furtherly move towards entrepreneurial position, which is limited by their low risk inclination.

\subsubsection{Ethnic Entrepreneurs}

Ethnic entrepreneurs are Indian workers who opted to become self-employed. They have the same background of both simple workers and Intrapreneurs, but they got the Italian citizenship, which removed the first barrier to become entrepreneurs. Moreover, thanks to positive individual disposal, they succeed in upgrading their professional and entrepreneurial skills and, finally, got the position of agricultural entrepreneurs. The rural context presented a unique set of challenges for these people and upward transition was encouraged by a sound entrepreneurial profile. Growth orientation and the risk taking are the main factor boosting a simple worker or an intrapreneur to become entrepreneurs. Individual values are also developed, being these 
workers are very optimistic and self-reliant. Moreover, high level of both entrepreneur and basic skills were found.

Nonetheless, one of the main problem these Indian entrepreneurs face is financial constraint, which limit the potential extent of entrepreneurship.

To sum up, the following Table 4 synthesises the results of empirical analysis, by evidencing the entrepreneurial traits of the three Indian ideal-types of workers.

Tab 4. A comparison between the entrepreneurial profile of Indian workers. Source: self-elaboration

\begin{tabular}{|l|l|l|l|}
\hline Economic values & Simple workers & Intrapreneurs & Entrepreneurs \\
\hline Innovativeness & Low & High & Very high \\
\hline Growth orientation & High & Very high & Very high \\
\hline Risk taking & low & Low & Very high \\
\hline Individual values & Simple workers & Intrapreneurs & Entrepreneurs \\
\hline Self-efficacy & Low & High & High \\
\hline Optimism & Low & Low & Very high \\
\hline Personal control & Low & high & Very high \\
\hline
\end{tabular}

\section{Conclusion and discussion}

In this paper, we have tried to analyse how immigrant workers may shape the rural countryside in Italy, through the lens of entrepreneurship. More precisely, by applying an "entrepreneurial identity model", we have identified three ideal-type of Indian workers (simple workers, intrapreneurs, entrepreneurs), characterised by different entrepreneurial profile acting as an engine or barrier to what we have labelled as "upward transition". The analysis is grounded on qualitative approaches, which have gained ground and are encouraged in recent studies on immigrant entrepreneurship (Dabić et al., 2020).

The idea of focusing on entrepreneurial orientation seems to offer an original perspective in addressing a dynamic process of social upgrading among immigrant workers. Our analysis confirms that in some cases, motivation for becoming rural entrepreneur is higher for immigrants, as revealed in recent researches (Gurău et al., 2020). Moreover, as evidenced by the interviewed Indians, hardworking activity boost some of them to try upward transition towards selfemployment, which configures what has been labelled by Dabić et al. (2020) as "forced" entrepreneurship. Additionally, a successful transition is stimulated by entrepreneurial talent: indeed, entrepreneurial orientation seems to be the engine for moving from simple workers to intrapreneurs and entrepreneurs in rural areas. As a matter of fact, the conditions of illegality, precariousness, scarce salary and limited rights for immigrant agricultural workers are closely interrelated to difficulties in obtaining residence permits, entrepreneurial licenses and inhibit the interests of immigrants in stabilising and upgrading in the primary sector.

As a consequence, strong push/pull motivations for entrepreneurship may be considered at the basis of entrepreneurial success of Indian workers. Despite the fact that replicative entrepreneurship seems to prevail with respect to innovative entrepreneurship (Blundel et al., 2018), it is possible to affirm that upward transition is possible in the presence of strong motivation and entrepreneurial identity. These characteristics allowed Indian immigrants to bridge the gap with local territorial contexts, through what Verver et al. (2020) identify as "mixed embeddedness" (ethnic community and wider social context). Consequently, as recently pointed out in constructivist approaches viewing immigrants as actors of local rural development (de Haas, 2010; Bock et al., 2016), immigrants have provided a contribution to shaping the rural countryside. This confirms that migration may have a positive effect on entrepreneurship in rural areas, within 
neo-endogenous processes of development, where foreign entrepreneurs play a relevant role (Deller et al., 2019)

Our analysis evidences some limitations, due to non-random sampling method we have adopted in this study. Therefore, further researches are necessary to deepen and better comprehend dynamics of ethnic entrepreneurship and to allow more generalizable results. Despite these limits, the research may address some policy implications at the beginning of the new programming period for rural development. As emphasised by Gurău et al. (2020, p.703), "the success of these policies depends, however, on properly understanding the determining factors and conditions of entrepreneurial activities". If immigrant entrepreneurs play a relevant role in rural businesses, it is of paramount importance to provide them with the same opportunities of domestic entrepreneurs, in terms of access to rural development policies, knowledge, training and education upgrading. More precisely, as underlined by Grubbström and Joosse (2019), immigrant farmers' vulnerability, networking and social capital are key resources to be supported to targeted policies. Moreover, removing barriers to set up new rural enterprises should be a priority for facilitating their entrance in the agricultural activity as entrepreneurs.

Our analysis revealed how the positive effects of entrepreneurship could be the basis of a new approach to ethnic entrepreneurship in agricultural sector, where diaspora knowledge networks (Meyer and Wattiaux, 2006) may represent an opportunity for all farmers to relaunch their role in agricultural entrepreneurship.

\section{Acknowledgement}

Authors would like to thank the anonymous referees for very useful suggestions.

\section{Academic references}

[1] Ahmad, N. \& Seymour, R. G. (2008). Defining entrepreneurial activity: Definitions supporting frameworks for data collection. Paris: OECD Publishing. DOI: 10.1787/243164686763.

[2] Anderson, B., Ruhs, M., Rogaly, B. \& Spencer, S. (2006). Fair Enough? Central and East European Migrants in Low-Wage Employment in the UK [Research Report]. University of Oxford.

[3] Aoyama, Y., Murphy, J. T. \& Hanson, S. (2010). Key concept in economic geography. London: SAGE.

[4] Baldoni, E., Coderoni, S. \& Esposti, R. (2017). Foreign workforce in Italian agriculture: a farm-level analysis. Bio-based and Applied Economics, 6(3), 259-278. DOI: 10.13128/BAE-23340259-278.

[5] Barbieri, A., Bari, G., Fondelli, S., Del Matto, L. \& Peca, M. (2015). Terra InGiusta. Rapporti sulle condizioni di vita dei braccianti stranieri in agricoltura. Rome: Medici peri Diritti Umani.

[6] Besser, T. L. \& Miller, N. (2001). Is the good corporation dead? The community social responsibility of small business operators. The Journal of Socio-Economics, 30(3), 221-241. DOI: 10.1016/S1053-5357(01)00094-4.

[7] Besser, T. \&. Miller, N. J. (2013). Community matters: Successful entrepreneurship in remote rural US locations. The International Journal of Entrepreneurship and Innovation, 14(1), 1527. DOI: $10.5367 /$ ijei.2013.0104.

[8] Blundel, R., Lockett, N. \& Wang, C. (2018). Exploring entrepreneurship. London: SAGE.

[9] Bock, B. B., Osti, G. \& Ventura, F. (2016). Rural migration and new patterns of exclusion and integration in Europe. In Shucksmith, M. \& Brown, D., eds., Routledge international handbook of rural studies; New York, Routledge. 
[10] Brzozowski, J. \& Lasek, A. (2019). The impact of self-employment on the economic integration of immigrants: Evidence from Germany. Journal of Entrepreneurship, Management and Innovation, 15(2), 11-28. DOI: 10.7341/20191521.

[11] Chreneková, M., Melichová, K., Marišová, E. \& Moroz, S. (2016). Informal employement and quality of life in rural areas of Ukraine, European Countryside 8(2), 135-146. DOI: 10.1515/euco-2016-0011.

[12] Coderoni, S., Macrì, M. C., Cardillo, C. \& Perito, M. A. (2018). Farms Employing Foreign Workers in Italy. An Analysis with Census Micro Data. German Journal of Agricultural Economics, 67(3), 185-202. DOI: 10.22004/ag.econ.309982.

[13] Coderoni, S. \& Perito, M. A. (2014). Migration from the Southern Mediterranean Countries. an analysis of some macro drivers. Global Environment, 7(2), 291-325. DOI: 10.3197/ge.2014.070203.

[14] Dabić, M., Vlačić, B., Paul, J., Dana, L-P., Sahasranamam, S. \& Glinka, B. (2020). Immigrant entrepreneurship: A review and research agenda, Journal of Business Research 113, 2538. DOI: 10.1016/j.jbusres.2020.03.013.

[15] Dana, L-P. (1997). The Origins of Self-Employment in Ethno-cultural Communities: Distinguishing Between Orthodox Entrepreneurship and Reactionary Enterprise, Canadian Journal of Administrative Sciences 14(1), 52-68. DOI: 10.1111/j.1936-4490.1997.tb00118.x.

[16] Dawson, A. \& Hjorth, D. (2011). Advancing Family Business Research Through Narrative Analysis, Family Business Review, 25(3), 339-355. DOI: 10.1177/0894486511421487.

[17] De Haas, H. (2010). The internal dynamics of migration processes. Journal of Ethnic and Migration Studies, 36(10), 1587-1617. DOI: 10.1080/1369183X.2010.489361.

[18] De Leo, S. \& Vanino, S. (2019). Immigrati in agricoltura in Italia: chi sono e da dove vengono. analisi multi-temporale dal 2008 al 2017. In: Macrì, M. C., ed., II contributo dei lavoratori stranieri all'agricoltura italiana (pp. 21-36). Rome: CREA.

[19] Deller, S., Kures, M. \& Conroy, T. (2019). Rural entrepreneurship and migration. Journal of Rural Studies, 66, 30-42. DOI: 10.1016/j.jrurstud.2019.01.026.

[20] De Rosa, M., Bartoli, L., Leonardi, S. \& Perito, M. A. (2019). The contribution of immigrants to multifunctional agricultural systems in Italy. Sustainability 11, 4641, DOI: $10.3390 /$ su11174641.

[21] De Rosa, M., Trabalzi, F. \& Pagnani, T. (2018). The social construction of illegality within local food systems. In Gray, A., Hinch, R., eds., A handbook of food crime. Bristol: Policy Press.

[22] Freire-Gibb, L. C. \& Nielsen, K. (2014). Entrepreneurship within urban and rural areas: creative people and social networks, Regional Studies, 48(1), 139-153. DOI: $10.1080 / 00343404.2013 .808322$.

[23] Grubbström, A. \& Joosse, S. (2019). New entrants in agriculture. The case of young immigrant farmers in Sweden, European Countryside 13(1), 22-37. DOI: 10.2478/euco2021-0002.

[24] Gurău, C., Dana, L-P., Light, I. (2020). Overcoming the Liability of Foreignness: A Typology and Model of Immigrant Entrepreneurs, European Management Review 17(3), 701-717. DOI: $10.1111 /$ emre.12392.

[25] Jones, T. P., McEvoy, D. \& Barrett, G. (1985). Small Business Initiative: Ethnic Minority Business Component. Swindon: Economic and Social Research Council.

[26] Kalantaridis, C. \& Bika, Z. (2006). In-migrant entrepreneurship in rural England: beyond local embeddedness. Entrepreneurship and Regional Development, 18(2), 109-131. DOI: $10.1080 / 08985620500510174$. 
[27] Kalantaridis, C. (2010). In-migration, entrepreneurship and rural-urban interdependencies: The case of East Cleveland, North East England. Journal of Rural Studies, 26(4), 418-427. DOI: 10.1016/j.jrurstud.2010.03.001.

[28] Kasimis, C. \& Papadopoulos, A. G. (2005). The multifunctional role of migrants in the Greek countryside: implications for the rural economy and society. Journal of Ethnic and Migration Studies, 31(1), 99-127. DOI: 10.1080/1369183042000305708.

[29] Kasimis, C., Papadopoulos, A. G. \& Zacopoulou, E. (2003). Migrants in rural Greece. Sociologia Ruralis, 42, 167-184. DOI: 10.1111/1467-9523.00237.

[30] Kordel, S. \& Lutsch, S. (2018). Status quo and potential of remigration among Transylvanian Saxons to rural Romania, European Countryside, 10(4), 614-633. DOI: 10.2478/euco-20180034.

[31] Lähdesmäki, M. \& Suutari, T. (2012). Keeping at arm's length or searching for social proximity? Corporate social responsibility as a reciprocal process between small businesses and the local community. Journal of Business Ethics, 108(4), 481-493. DOI: 10.1007/s10551-011-1104-6.

[32] Low, W. \& Davenport, E. (2018). Fair trade laws, labels and ethics. In Gray, A., Hinch, R., eds., A handbook of food crime Bristol: Policy Press.

[33] Macrì, M. C., ed. (2019). Il contributo dei lavoratori stranieri all'agricoltura italiana. Rome: CREA.

[34] McElwee, G. \& Smith, R. (2012). Classifying the strategic capability of farmers: a segmentation framework. International Journal of Entrepreneurial Venturing, 3(4), 111131. DOI: 10.1504/IJEV.2012.046517.

[35] McGranahan, D. A., Wojan, T. R. \& Lambert, D. M. (2011). The rural growth trifecta: outdoor amenities, creative class and entrepreneurial context. Journal of Economic Geography, 11(3), 529-557. DOI: 10.1093/jeg/lbq007.

[36] Methorst, R., Roep, D., Verstegen, J. \& Wiskerke, J. S. C. (2017). Three-Fold Embedding: Farm Development in Relation to Its Socio-Material Context. Sustainability, 9(10), 1677. DOI: 10.3390/su9101677.

[37] Meyer, J. B. \& Wattiaux, J. P. (2006). Diaspora knowledge networks: vanishing doubts and increasing evidence. International Journal on Multicultural Societies, 8, 4-24.

[38] Mitchell, R. K., Smith, J. B., Morse, E. A., Seawright, K. W., Paredo, A. M. \& McKenzie, B. (2002). Are entrepreneurial cognitions universal? Assessing entrepreneurial cognitions across cultures. Entrepreneurship Theory \& Practice, 26, 9-32. DOI: $10.1177 / 104225870202600402$.

[39] Nori, M. (2017). Immigrant Shepherds in Southern Europe. Berlin: Heinrich Böll Foundation.

[40] Omisakin, O. M., Nakhid, C., Littrell, R. \& Verbitsky, J. (2016). Entrepreneurial Orientation among Migrants and Small and Medium Enterprises. Journal of Business Administration Research, 5(1): 7-22. DOI: 10.5430/jbar.v5n1p7.

[41] Owusu-Daaku, K. \& Onzere, S. (2019). Ethnography in Agricultural Research: A Tool for Diagnosing Problems and Sustaining Solutions. African Journal of Food, Agriculture, Nutrition and Development, 19(01),14090-14112. DOI: 10.18697/ajfand.84.BLFB1032.

[42] Pisacane, L. (2017). Lavoratori immigrati nell'agricoltura italiana: numeri e sfide verso una prospettiva di integrazione. In: Bonifazi, C., ed., Migrazioni e integrazioni nell'Italia di oggi, (pp. 157-170). Roma: Istituto di Ricerche sulla Popolazione e le Politiche Sociali. DOI: $10.14600 / 978-88-98822-12-6$.

[43] Rye, J. F. \& Andrzejewska, J. (2010). The structural disempowerment of Eastern European migrant farm workers in Norwegian agriculture. Journal of Rural Studies, 26(1), 41-51. DOI: 10.1016/j.jrurstud.2009.06.003. 
[44] Rye, J. F. \& Slettebak, M. H. (2020). The new geography of labour migration: EU11 migrants in rural Norway. Journal of Rural Studies, 75, 125-131. DOI: 10.1016/j.jrurstud.2020.01.014.

[45] Saxenian, A. (2002). Silicon Valley's new immigrant high-growth entrepreneurs. Economic Development Quarterly, 16(1), 20-31. DOI: 10.1177/0891242402016001003.

[46] Sahin, M., Nijkamp, P. \& Baycan, T. (2007). Migrant entrepreneurship from the perspective of cultural diversity. In Dana, L. P., ed., Handbook of research on ethnic minority entrepreneurship (pp. 99-113). Cheltenham Edward Elgar Publishing.

[47] Smith, R. \& McElwee, G. (2014). Developing qualitative research streams relating to illegal rural enterprise. International journal of entrepreneurial behaviour and research, 21(3), 361388. DOI: 10.1108/IJEBR-01-2014-0019.

[48] Steiner, A. \& Atterton, J. (2015). Exploring the contribution of rural enterprises to local resilience. Journal of Rural Studies, 40, 30-45. DOI: 10.1016/j.jrurstud.2015.05.004.

[49] Stockdale, A. (2006). Migration: Pre-requisite for rural economic regeneration? Journal of Rural Studies 22(3), 354-366. DOI: 10.1016/j.jrurstud.2005.11.001.

[50] Verver, M., Roessingh, C. \& Passenier, D. (2020). Ethnic boundary dynamics in immigrant entrepreneurship: a Barthian perspective. Entrepreneurship \& Regional Development 32(910), 757-782. DOI: 10.1080/08985626.2020.1757160.

[51] Vesala, K. M., Peura, J. \& McElwee, G. (2007). The split entrepreneurial identity of the farmer. Journal of Small Business and Enterprise Development, 14(1), 4863. DOI: $10.1108 / 14626000710727881$.

[52] Wang, C. L. \& Altinay, L. (2012). Social embeddedness, entrepreneurial orientation and firm growth in ethnic minority small businesses in the United Kingdom. The International Small Business Journal, 30(1), 3-23. DOI: 10.1177/0266242610366060.

[53] Webb, J. W., Tihanyi, L., Ireland, R. D. \& Sirmon, D.G. (2009). You say illegal, I say legitimate: entrepreneurship in the informal economy. Academy of Management Review, 34, 492-510. DOI: 10.5465/amr.2009.40632826.

[54] Yin, R. (2008). Case Study Research: Design and Methods. London: Sage.

[55] Zhou, M. (2004). Revisiting ethnic entrepreneurship: convergences, controversies, and conceptual advancements. The International Migration Review, 38(3), 1040-1074. DOI: $10.1111 /$ j.1747-7379.2004.tb00228.x.

\section{Other sources}

[56] Bluestein, A. (2015). The most entrepreneurial group in America wasn't born in America. Inc. Magazine. February. Available at http://www.inc.com/magazine/201612/ leighbuchanan/state-of-entrepreneurship-2017.html (Accessed 13 September 2020).

[57] European Union (2018). Integration of Immigrants in the European Union. Vol. 469, Special Eurobarometer. Bruxelles.

[58] European Commission-Joint Research Centre (2019). Migration in EU rural areas, European Commission, Luxembourg.

[59] Eurostat (various years). EU labour force survey. https://ec.europa.eu/eurostat/web/microdata/european-union-labour-force-survey.

[60] ISTAT - Italian National Institute of Statistics (various years); Data on international migration and the foreign presence in Italy. www.istat.it.

[61] MAC (Migration Advisory Committee) (2013). Migrant Seasonal Workers. The impact on the horticulture and food processing sectors of closing the Seasonal Agricultural Workers Scheme and the Sectors Based Scheme. London. 